\title{
PROPOSAL PENAWARAN PEMBUATAN WEBSITE SEKOLAH ONLINE
}

\author{
NAMA : FITRI ANNISA PURBA \\ NIM : 0702201144 \\ KELAS : SISTEM INFORMASI 4
}

MATA KULIAH : SISTEM INFORMASI MANAJEMEN DOSEN PENGAMPU : Dr. YAHFIZAM, S.T., M.Cs.

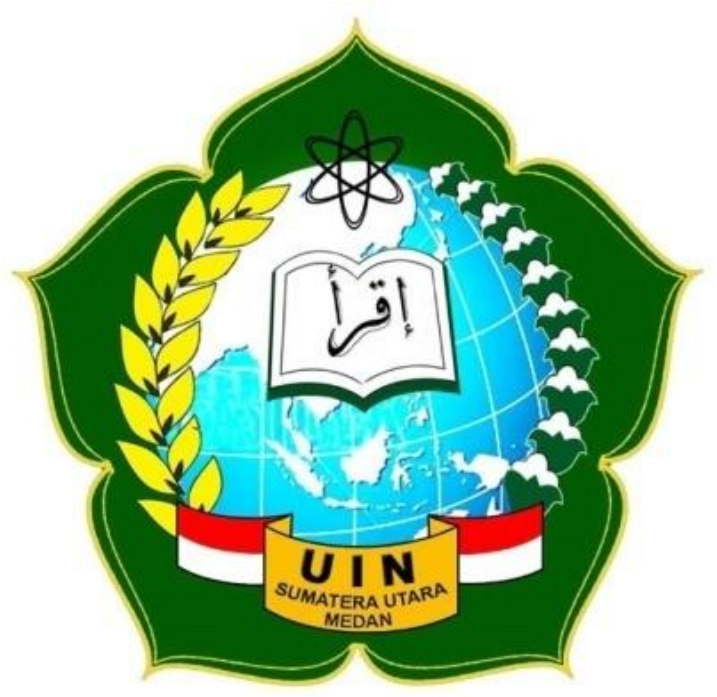

UNIVERSITAS ISLAM NEGERI SUMATERA UTARA FAKULTAS SAINS DAN TEKNOLOGI JURUSAN SISTEM INFORMASI T.A 2020/2021 


\section{A. PENDAhUluan}

Permintaan individu untuk sifat pendidikan selama jangka panjang lebih tinggi. Sebagai perluasan yang tak dapat disangkal dari ilmu pengetahuan dan inovasi telah mendorong organisasi derajat fluktuasi dan fase pelatihan untuk berhenti untuk mempertahankan kekuatan sosial dan pembentukan pendidikan, namun untuk terus dalam perubahan kreatif dalam sudut yang berbeda untuk menjauhkan diri dari ditinggalkan oleh individu yang hidup pada masa globalisasi.

Memahami hal ini, sekolah sebagai pemecah masalah di mata publik harus terus membuat perubahan stabil dengan elemen perbaikan masyarakat dalam iptek. Untuk membantu bahwa pengerahan tenaga memerlukan sarana dan landasan pendukung untuk visi dan misi sekolah.

PC berbasis data inovasi mungkin media terbaik di data sekolah. Pemanfaatan Internet saat ini juga mulai meningkat dalam pelatihan, memanfaatkan itu sulit asa rileks pencarian untuk data di Internet namun selain itu telah mencakup inovasi Internet asa mendistribusikan media

Luar biasa dibandingkan dengan organisasi praktik lain dari program pelatihan sekolah adalah pengembangan situs sekolah melihat asa perancah brilian untuk masa depan yang gemilang, khususnya di situs ini adalah kerangka kerja yang memungkinkan pengecekan nilai pengganti asan materi penilaian yang wal/ penjaga dapat layar secara online tanpa menampilkan perbaikan dalam halaman. Selain itu, ada berbagai data sekolah yang menarik bagi orang-orang untuk membayangkan sekolah-sekolah.

Perubahan data adalah salah satu kekuatan situs yang unik, mengingat fakta bahwa sifat dasar data satu adalah berkelanjutan dan state-of-the-art. Jadi penggunaan cepat dan sederhana dari mengubah kerangka kerja adalah kebutuhan mutlak. Pembuatan situs adalah alternatif terakhir ketika individu semakin terbiasa dengan inovasi berbasis web. 


\section{B. TUJUAN}

Pembuatan website ini antara lain bertujuan sebagai:

1. Informasi sekolah dapat diperoleh dengan mudah dimana saja dan kapan saja.

2. Meningkatkan tali silaturrahmi antara alumni dengan alumni, alumni dengan staff pengajar, antara staff dengan orang tua/wali.

3. Meningkatkan kredibilitas sekolah dimata masyarakat dalam kesungguhanya meningkatkan kualitas pendidikan.

\section{MANFAAT}

Dari sudut manapun, tampaknya bahwa potongan inovasi data ini sangat penting bagi sekolah. Banyak keuntungan dapat diperoleh dari kehadiran data media sekolah. Situs sekolah ini menyerupai sebuah jendela besar di mana orang-orang di seluruh dunia dapat melihat keberadaan dan latihan sekolah. Bukan hanya itu, para tamu internet bisa bekerja sama dengan para pemimpin web. Sebagian keuntungan yang dimiliki beberapa situs untuk lingkaran yang berbeda:

1. Bagi Lembaga Pendidikan :

a. Sebagai sarana dan media untuk mempromosikan SEKOLAH kepada masyarakat sekitar.

b. Sebagai media untuk meningkatkan mutu dan kualitas pendidikan yang berbasis teknologi informasi komputer melalui peran serta orang tua /wali dalam memonitoring kegiatan akademik siswa secara online.

2. Bagi Siswa :

Presentasi kemajuan yang tidak secara langsung dalam menunjukkan latihan pembelajaran campuran untuk berubah menjadi sangat mengenal pemanfaatan inovasi data. Mahasiswa pengganti menjadi lebih mudah untuk mendapatkan data dan dapat mengambil peran yang berfungsi dalam perkumpulan online yang diberikan oleh situs untuk mengadakan percakapan terbuka dari para tamu laman web kerabat mereka.

3. Bagi Alumni :

Kerinduan akan almamater sering dialami banyak orang. Khususnya bagi individu-individu yang telah berbuah, secara teratur ada penyelidikan dalam jiwa kita mengenai kehadiran sekolah-sekolah sebelumnya. Kerinduan pendidik yang dipuja, ingatan struktur sekolah dan kolega tidak diragukan lagi akan dibagi oleh semua orang. Kehadiran situs sekolah akan menghubungkan perasaan ini dengan hubungan yang penuh gairah.

4. Bagi Calon Siswa :

Para calon pengganti yang telah direncanakan mungkin mempertimbangkan sebelum memasuki sekolah yang sangat diminati. Semua pelatihan sekolah saat ini, jabatan yang sudah ada dan pencapaian skolastik dapat dijadikan pemikiran untuk menggantikan pilihan sekolah yang akan dimasukkan.

5. Bagi Orang Tua dan Masyarakat :

Situs sekolah dapat menjadi alat yang sangat diperlukan untuk memperoleh data dari berbagai jaringan dan orang understudies'. Dengan situs lokal sekolah daerah 
dan wali akan secara konsisten menyaring keadaan sekolah saat ini dengan data yang diberikan di situs. Nilai anak-anak juga dapat dilihat dengan merosotnya kualitas yang tersebar melalui situs.

\section{GAMBARAN UMUM IMPLEMENTASI WEBSITE}

Sesuai dengan rancangan tujuan dan manfaat yang akan dipetik dari pembuatan website ini, bentuk gambaran umum implementasi website yang akan dibangun antara lain memiliki fasilitas sebagai berikut :

1. CMS (Content Management System)

Seperti yang ditunjukkan oleh kerangka ini, kandungan substansi web akan lebih state-of-the-art dan mudah beradaptasi. Administrator web yang akhirnya ditunjuk oleh sekolah untuk menangani web akan lebih mudah untuk membuat perubahan pada data yang disiarkan di situs sekolah. Data, misalnya, catatan instruktur, profil sekolah, pencapaian sekolah, DLL dapat dibuat berubah sekarang dan lagi secara efektif dan lebih cepat. Beberapa data lain yang dapat digulung secara online ations ations, data kerja, data hibah, dan laporan sekolah, staf dan guru, artikel, buku the and so on.

2. Galeri Sekolah

Pameran sekolah adalah halaman yang mengizinkan sekolah untuk memperlihatkan foto-foto dari pemeragaan latihan, bermacam-macam rencana imajinatif dari studi, dan prestasi sekolah lebih sederhana. Para tamu bisa melihat dan selanjutnya mengomentari konsekuensi kecerdasan sekolah.

3. Forum Diskusi Online

Pengumpulan percakapan online adalah ruang percakapan intuitif yang dapat diikuti oleh mahasiswa, instruktur, staf dan lulusan kelas mana pun. Dalam pemanfaatan percakapan ini, dibutuhkan suatu tahap pencatatan yang, dengan demikian, dapat mengikuti percakapan di dalamnya. Percakapan diawasi oleh administrator yang ditugaskan oleh sekolah dan pengaturan diskusi dapat didalangi sebagai keinginan administrator.

4. Buku Tamu

Mengizinkan para tamu ke situs sekolah untuk mengirimkan kritik ke eksekusi situs-situs yang berlangsung selama periode tertentu. Dengan kehadiran ketua situs ini akan lebih mudah untuk mewajibkan kerinduan dari tamu web. Data yang terkait ini akan membuatnya lebih mudah untuk memperkenalkan data yang benar-benar menguntungkan tamu.

5. Status Staff Online

Status tentang kehadiran staf online atau manajer situs menggunakan kantor yahomassager gratis. Yahoo massager adalah administrasi bicara online dari organisasi terbesar Yahoo.com yang sekarang telah menjadi standar interchange online terbesar di dunia. Kantor ini memberdayakan staf online untuk dicapai oleh tamu langsung, bahkan dengan korespondensi memberdayakan korespondensi tak terbatas. 
6. Link Referal

Referensi dari luar dapat digunakan sebagai koneksi ke situs-situs Internet yang diidentifikasi sebagai situs sekolah.

7. Blog Site

Blog Website diberi komponen tambahan dalam bundel sebagai menulis untuk sebuah blog di subdomain yang dipilih dari halaman web.

\section{E. PERKIRAAN ALOKASI WAKTU PENGERJAAN}

\begin{tabular}{|l|c|}
\hline \multicolumn{1}{|c|}{ Rencana Kerja } & Hari \\
\hline Penyusunan konsep website & 1 \\
\hline Pengumpulan data (graphic, materi, teks, dll) & 1 \\
\hline Perancangan konsep layout website & Hari ke-3 \\
\hline Rancangan web & 1 \\
\hline Pengerjaan Website : & 1 \\
> Pengerjaan HTML dan Script & 1 \\
> Pengeditan graphic / gambar & Hari ke-6 \\
> Pengerjaan script PHP \& MySQL & 1 \\
\hline Presentasi Website & Hari ke-7 \\
\hline Perbaikan Website &
\end{tabular}

\section{F. RINCIAN ITEM WEB}

Estimasi perancangan dan gambaran inplementasi website yang ditawarkan :

\section{Profile Sekolah}

(sejarah, visi and misi, hierarkis desain, komite pendidikan)

2. Staf Pengajar

(Daftar Guru, Riwayat Pendidikan Guru, Prestasi Guru)

\section{Program Kerja}

(Program kerja, Kalender akademik )

\section{Berita}

( Berita tentang Sekolah, fasilitas sekolah ;Perpustakaan, Mushola, Kantin, Lapangan Olahraga, Laboratorium bahasa, laboratorium komputer, Parkir)

\section{Kegiatan}

(OSIS, pramuka, PMR, kekasih alam, perjalanan lapangan, latihan tahunan, kelompok drum, paskibraka, perkumpulan belajar)

\section{Alumni}

(Data Alumni, Informasi Alumni, Jadwal Reuni)

\section{Siswa}

(Data Siswa, Informasi Siswa )

\section{Galeri Photo}

(foto sekolah seperti struktur, kantor sekolah, gerakan, pengenalan, pencapaian, studi kunjungan) 


\section{Buku Tamu}

(Tampilan Buku Tamu, Form Isian Buku Tamu)

\section{E-Learning}

( Belajar Online, Topik Pelajaran, Download Materi Pelajaran)

\section{Admin Control Panel}

(Halaman Admin Untuk Manajemen Website dengan Mudah)

\section{Dan Penambahan Seperlunya...!}

\section{G. MASA GARANSI}

Kami memperbolehkan multi bulan jaminan setelah distribusi situs. Selama masa garansi ini, tidak dikenakan biaya tambah jika terdapat eror pada halaman web. Kami juga menyediakan layanan maintenance (perawatan web) setelah masa garansi berakhir jika masih diperlukan.

\begin{tabular}{|c|l|c|}
\hline No & \multicolumn{1}{|c|}{ Keterangan } & Biaya \\
\hline 1 & Desain dan Perancangan Website (Online) & Rp. 1.000.000,- \\
2 & Registrasi Domain SCH.ID Dibayar Setahun Sekali & Rp. 110.000,- \\
3 & Hosting Dibayar Setahun Sekali & Rp. 950.000,- \\
4 & Pelatihan Web Admin dan Control Panel untuk 2 peserta & Rp. 500.000,- \\
\hline & Total : & Rp. 2.560.000,- \\
\hline
\end{tabular}

D Dalam proposal ini sudah masa aktif 1 tahun, untuk tetap menikmati fasilitas website $\neg$ cukup melakukan perpanjangan domain dan hosting saja. Untuk model dan penawaran yang lain dapat menyesuaikan kebutuhan pemohon.

$>$ Untuk Domain .SCH.ID Syarat : KTP Penanggung Jawab, Surat Permohonan $\neg$ Kepala Sekolah, Surat Kuasa.

> Untuk Domain .COM/.NET/.ORG harga Rp. 100.000,- per tahun tanpa syarat. $\neg$ Untuk biaya maintenance ditambah Rp. 500.000,- 


\section{H. PEMBAYARAN}

Untuk tetap bekerja dengan strategi pemasangan untuk klien dan klien yang diharapkan, saat ini kami memberikan opsi berbeda dengan strategi untuk angsuran:

Nomor Rekening. 1771291202

Kantor Cabang. $\quad$ KCP Madiun

Atas Nama Fitri Annisa Purba

Kantor Cabang. KCP Wungu, Madiun

Atas Nama. $\quad$ Fitri Annisa Purba

\section{KETENTUAN-KETENTUAN LAIN}

Ketentuan lain yang sifat dan bentuknya tidak mengikat dapat dibicarakan secara kekeluargaan.

\section{J. PENUTUP}

Demikian Proposal Penawaran Pembuatan Website Sekolah ini dibuat sebenarbenarnya sebagai bentuk kerja sama semoga bisa bermanfaat sebaik-baiknya.

Atas kerjasamanya kami ucapkan terima kasih. 


\section{LAMPIRAN 1}

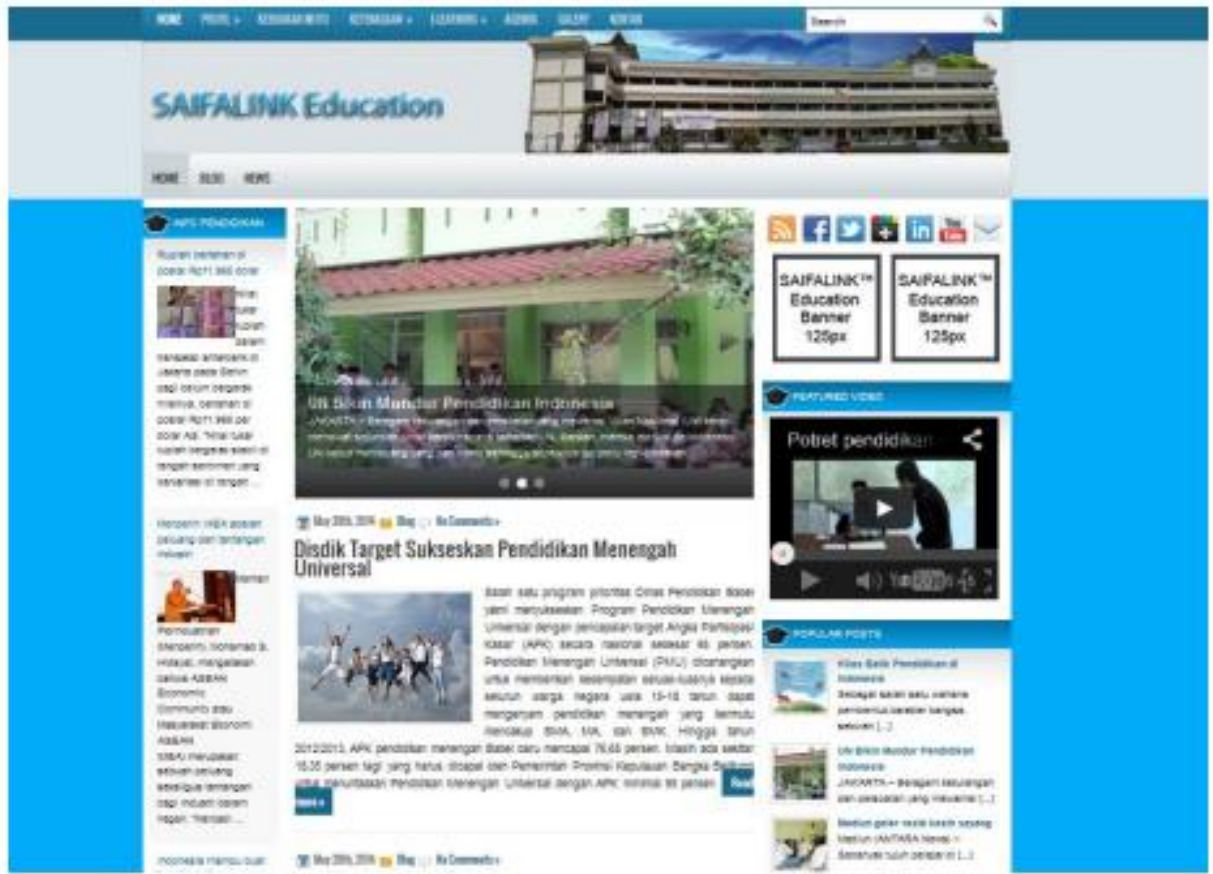

http://www.gusipul.com/school/

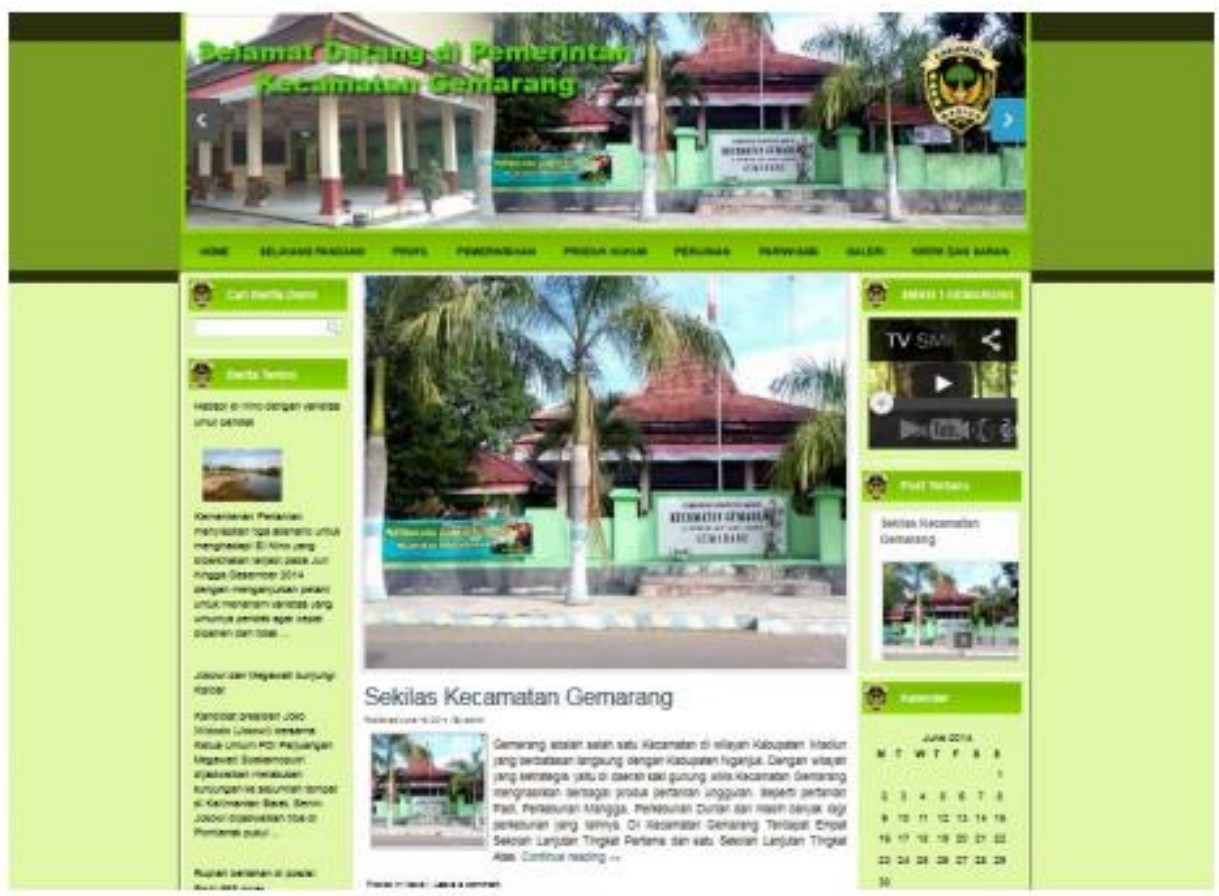

http://www.gusipul.com/gemarang/ 


\section{LAMPIRAN 2}

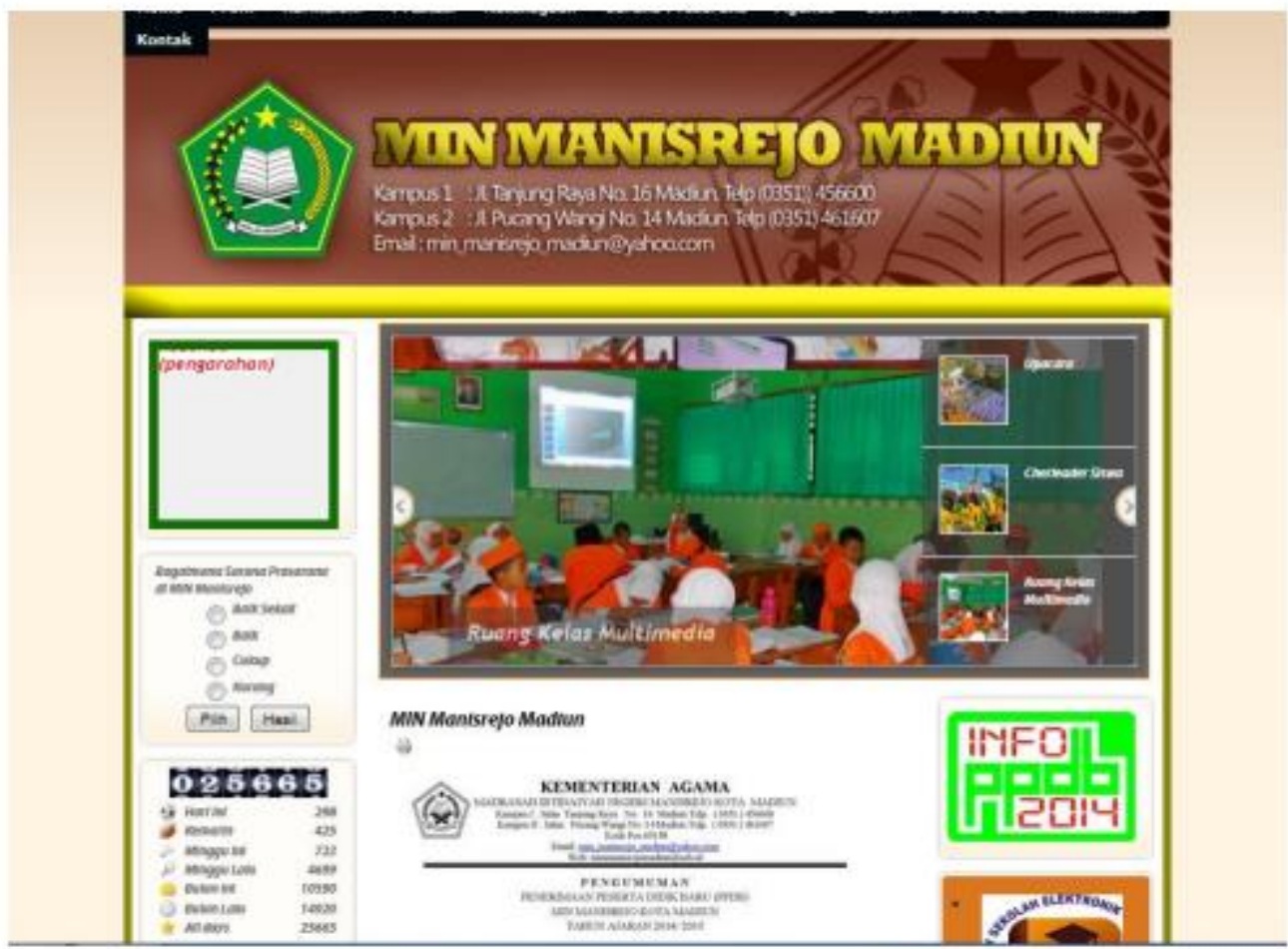

http://minmanisrejomadiun.sch.id/

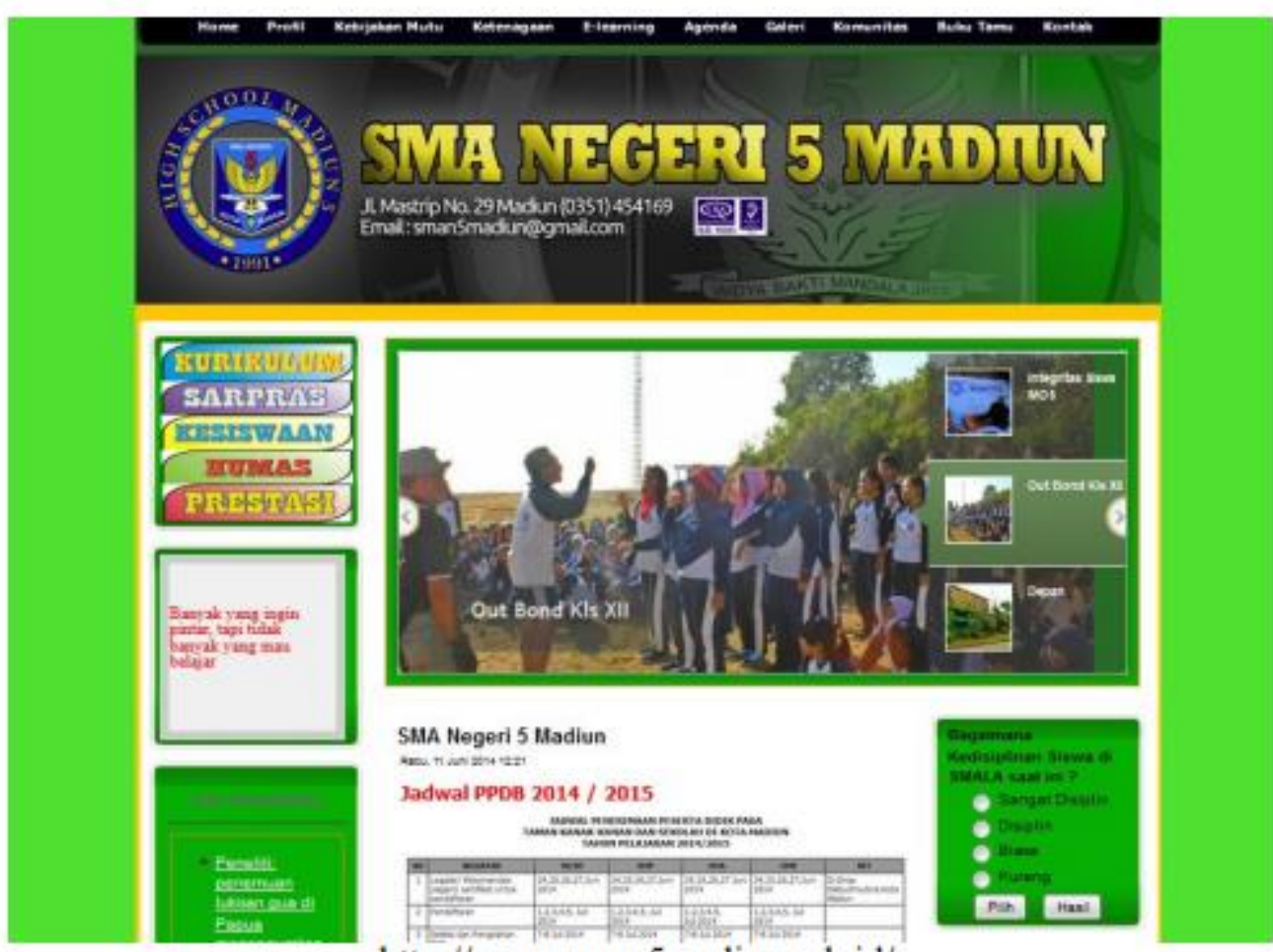

http://www.sman5madiun.sch.id/ 